Зущенко Наталія Андріївна, стариий викладач кафедри бандури та кобзарського мистецтва, Київський національний університет культури імистецтв

\title{
АНАТОЛІЙ ЮХИМОВИЧ ГРИЦАЙ - ЗАСНОВНИК ПРОФЕСІЙНОГО АКАДЕМІЧНОГО БАНДУРНОГО ВИКОНАВСТВА НА РІВНЕНЩИНІ
}

Стаття містить реконструкиію основних етапів життєвого иляху та діяльності бандуриста, викладача, диригента, громадського діяча, фундатора професійного бандурного виконавства на Рівненщині-А. Ю. Грицая. У контексті дослідження здійснено аналіз засад формування його творчої особистості та характеру виконавського, викладащького, композиторського, організаційного та диригентського досвіду.

Ключові слова: фундатор професійного бандурного виконавства, педагогічна діяльність, бандурне виконавство, професіоналізація освіти.

Статья содержит реконструкиию основных этапов жизненного пути $и$ деятельности бандуриста, преподавателя, дирижера, общественного деятеля, основателя профессионального бандурного исполнительства в Ровенской области A. Е. Грицая. В контексте исследования осуществлен анализ принщипов формирования его личности и характера исполнительского, преподавательского, композиторского, организационного и дирижерского опыта.

Ключевые слова: основатель профессионального бандурного исполнительства, педагогическая деятельность, бандурное исполнительство, профессионализачия образования.

The article includes the reconstruction of the main life phases and activities of bandura player, teacher, conductor, public figure, the founder of professional bandura performance in the Rivne region - Anatoly Gritsai. In the context of the research the principles which formed his creative personality and the character of his performing, teaching, composing, conducting and organizing experience were analyzed.

Key words: founder of professional bandura performance, educational activities, bandura performance, professionalization of education.

У сер. ХХ ст. в Україні відбулося значне піднесення бандурного мистецтва, що було зумовлене процесом його професіоналізації, центрами якої стали щойно відкриті класи бандури в Київській (1950р.) та Львівській (1954р.) консерваторіях. Результатом їх роботи стало забезпечення професійними кадрами класів бандури в розгалуженій системі спеціалізованих музичних навчальних закладів і започаткування двох академічних виконавських шкіл, які плідно працюють і дотепер.

Бандура стала одним із найпопулярніших інструментів у мистецькому житті сучасного Рівного. Відомі рівненські бандуристи - заслужена артистка України Галина 
Топоровська, Оксана Крук, Назар Волощук, Мирослава Очеретяна, Тетяна Бенедюк, сестри Ірина та Наталія Свтушок та ін. виявляють виконавську активність і наполегливість у розвитку професійного бандурного виконавства. Та найбільший внесок у популяризацію бандурного виконавства на Рівненщині вніс бандурист, викладач, громадський діяч, композитор, поет - Анатолій Юхимович Грицай. Саме завдяки його праці відбулося піднесення академічного бандурного виконавства на Рівненщині професійний рівень.

Творчу діяльність А. Ю. Грицая досліджували українські мистецтвознавці, культурні діячі, журналісти. Так, А. І. Дацков присвятив одну зі своїх праць життю та творчій діяльністі Анатолія Юхимовича Грицая. Т. Прокопович проаналізувала спадшину видатного бандуриста та композитора. Пропагандист українського кобзарства і бандури, меценат Микола Володимирович Досінчук-Чорний висвітлив творчу та громадську діяльність А. Грицая.

Аналіз вказаних праць дає підстави стверджувати, що нині не існує спеціального науково дослідження, яке б комплексно висвітлило творчу спадщину видатного бандуриста та композитора. Потребують виявлення та висвітленя деякі маловідомі факти життя і творчості бандуриста. Адже саме А. Ю. Грицай був першим професійним бандуристом на Рівненщині.

Мета статті- висвітлити шляхи формування особистості А. Ю. Грицая у широкому культурному контексті.

Завдання статті - долідити творчий вклад А. Ю. Грицая в розвиток бандурного мистецтва в Україні.

3 дитинства А. Ю. Грицай відчув потяг і любов до музики, до слова та письменства. Від старшої сестри, яка здобувала освіту в Київському музичному училищі, навчився грати на кобзі. Але справжньої виконавської майстерності А. Ю. Грицаю допоміг набути його вчитель, відомий в Україні виконавець-кобзар, диригент і педагог В. А. Кабачок.

У 1952 р. Анатолій Грицай закінчив Київське музичне училище ім. Р. М. Глієра і вступив до Київської державної консерваторії ім. П. І. Чайковського, де продовжував навчатися у В. А. Кабачка. Він зі своєю сестрою Раєю часто бували в гостях у свого вчителя, який був не просто викладачем зі спеціальності, а батьком, якого вони в дитинстві не мали. В. Кабачок був учителем життя, який зумів відкрити двері у безмежний світ мистецтва своїм учням.

Під час навчання в консерваторії Анатолій Юхимович розпочав свою артистичну та педагогічну діяльність. Він працював викладачем по класу бандури в Київській вечірній музичній школі для дорослих, а згодом, коли В. Кабачок почав хворіти, адже роки репресій дали про себе знати, він викладав у Київському музичному училищі ім. Р. М. Глієра (1955-1956). Грав на бандурі в оркестрі славетного народного хору під керівництвом Григорія Верьовки та ансамблю пісні і танцю під керівництвом Павла Вірського, гастролював, утверджував себе як майбутній бандурист і педагог. За роки навчання в Києві він вбирав у себе всі знання, які могли знадобитися у майбутньому, спілкувався з кращими музикантами і слухав високопрофесійних виконавців. Також у консерваторії В. Кабачком було створене перше чоловіче тріо у складі А. Маціяки, А. Грицая та В. Лапшина, котрі вели активну спільну виконавську діяльність. 15 червня 
1957 р. пішов з життя В. А. Кабачок, і тому А. Грицай закінчував консерваторію в класі народного артиста України А. М. Бобиря.

Анатолій Юхимович їде за направленням працювати в Рівненське музичне училище, де починає буквально «з нуля», адже, класу бандури як такого ні в училищі, ні в музичних школах не було. Йому судилося стати першим у цьому краї бандуристомпедагогом, який усе своє життя відав на вівтар педагогіки і невмирущого кобзарського мистецтва.

У гуртках художньої самодіяльності бандура не мала широкого розповсюдження через брак професійних музикантів і значний дефіцит цих інструментів у продажу. І лише з приїздом Анатолія Грицая цей легендарний інструмент почав здобувати справжню популярність.

До приїзду А. Грицай у Рівне (1958 р.) в музичному училищі працювало тільки три відділи: хоровий, духовий і народний. На останньому вже працював його колега i товариш Ю. М. Глотко. Першими ученицями Анатолія Юхимовича стали Віра Бордюг і Мирослава Хомкова. А учень класу домри Йосип Яницький перевівся в клас молодого педагога і став першим його випускником. Згодом уся його родина стала кобзарською. Йосип Яницький - залужений діяч мистецтв, його дружина Марія і син Тарас-заслужені артисти України, син Роман - соліст національної капели бандуристів ім. П. Майбороди.

Учнів А. Грицая багато, насамперед, на Рівненщині. Варто зазначити, що в усіх 35 дитячих музичних школах і музичних закладах є його вихованці, які викладають, пропагують і підносять справу кобзарського мистецтва. Чимало їх і в усій Україні: у Львові і Полтаві, у Чернівцях і Севастополі, у Черкасах і Вінниці, у Миколаєві і Києві... . Це артисти філармоній, керівники й учасники творчих колективів, викладачі музичних шкіл. Багато з них стали лауреатами різноманітних мистецьких конкурсів. Серед його учнів: Катерина Маслій, Тетяна Бенедюк (вчитель бандури музичної школи № 1, учасник тріо «Срібна терція»), Світлана Чабан, Людмила Фусик (учитель класу бандури музичної школи № 1), Тамара Мирук (учитель музичної школи № 2), заслужені артисти України Галина Топоровська, Василь Пиндик, Йосип Яницькай, заслужена артистка республіки Крим Вікторія Накорнєєва, заслужений працівник культури України Валентина Кузьменко і багато ін.

У Анатолія Юхимовича був зошит, в якому він записував усіх своїх випускників $\mathrm{i}$ їхні здобутки на творчій ниві протягом життя. Таких записів було понад 100, там він зазначав подальше місце роботи, різні газетні статті про їхню діяльність. Поряд 3 основною педагогічною роботою в музичному училищі, він у різні роки викладав у Рівненському державному педагогічному інституті культури (нині РДГУ), ДМШ №1 ім. М. В. Лисенка.

Він організовував різноманітні концерти, де виступав і сам, і зі своїми учнями, вони грали в різних навчальних закладах, трудових колективах міста та області. Після кожного академконцерту студенти виконували кращі твори в дитячій музичній школі №1 і №2. На всіх творчих зустрічах Анатолій Юхимович розповідав про бандуру, їі історію, демонстрував її звучання, показував ії переваги. Він завжди прагнув донести українське слово до публіки.

Велика заслуга Анатолія Грицая в організації ансамблів бандуристів: дуетів, тріо, квартетів. Зокрема найвідомішим став «Золотий квартет» у складі Свгенії Висоцької, 
Наталки Грицай, Ніни Марчук та Євгенії Ігнатієвої. У цьому квартеті співала його дружина Наталка. У 1959 р. на конкурсі в Білорусії дівчата отримали срібну медаль та визнання вимогливої публіки. Виступаючи на конкурсі Всесоюзного фестивалю самодіяльної народної творчості 1967 р., присвяченого 50-річчю Великої Жовтневої соціалістичної революції, вони отримали «Золоті медалі». За таку високу нагороду квартет назвали «Золотим».

У 1960 р. їх знімали у фільмі про самодіяльність в Україні, в телепередачі «Карусель» у Москві. А згодом вони записувалися на Національному радіо в Києві та їздили в Ленінград для участі у фестивалі «Білі ночі». Квартет виступав і був добре знаний по всій Україні та за іiі межами. Їх неодноразово вітали оплесками вдячності за неповторний український спів жителів Німеччини, Польщі, Чехії, Угорщини, Болгарії, Будапешта, Ленінграда та ін. Проіснував квартет 25 років, постійно радуючи концертами слухачів. 19 грудня 1983 р. відбувся ювілейний концерт ансамблю.

«Золотий» квартет був гордістю Рівненщини. Їх любили і шанували за натхненну пісню, за правдиве українське слово. Ті старання Анатолія Грицая згодом дали свої результати. Учні Анатолія Юхимовича почали створювати свої колективи або стали учасниками в ансамблях різного складу. Більшість ансамблів міста та області $є$ його «дітищем», адже він спонукав до створення таких колективів своїх вихованців. Для багатьох із них писав аранжування пісень.

Рівненська капела бандуристок у Будинку творчої самодіяльності була заснована Анатолієм Юхимовичем навесні 1971 р. Капела неодноразово виступала по Львівському та Київському телебаченню. У виконанні колективу часто звучали твори по обласному та республіканському радіо. Колектив двічі ставав золотим лауреатом фестивалів самодіяльної художньої творчості, брав участь у трьох урядових концертах, шість разів виступав на сцені Київського палацу «Україна», тричі під час звітних концертів Рівненщини. Капела часто з'являлася перед глядачами з власними концертними програмами, частина 3 яких складалася з двох відділів. Бандуристки неодноразово виступали в Мокві, Мінську та Києві. Колектив постійно давав концерти в Рівному та області. Завдяки активній концертній діяльності, учасники капели набували великої концертної практики, сценічного досвіду та вміння працювати в ансамблі. Загальний репертуар колективу становив понад 100 творів, 3 яких 20 - композиції Анатолія Юхимовича.

Не маючи звань і нагород, будучи старшим викладачем, він став Великим Учителем. І не тільки для бандуристів, а й для багатьох, які не займалися в його класі, проте мали змогу грати в самодіяльній капелі, а ще для багатьох поколінь студентів, завдяки постійно діючій художньо-публіцистичній виставці, яку він організовував у музичному училищі більше 40 років поспіль на громадських засадах. А. Грицай був членом Всеукраїнського товариства «Просвіта». А з 1994 р. очолював Рівненське обласне відділення Національної спілки кобзарів України. Він систематично публікував музично-критичні статті та поезію в обласній і республіканській пресі.

Без перебільшення Анатолія Юхимовича можна назвати літописцем концертного життя класу бандури, училища та концертно-театрального життя міста і області. Живе Анатолій Грицай у тих багатотомних щоденниках, які вів щезі шкільних років, і в листах, 
які, власне, є віддзеркаленням його роботи, помислів, роздумів, сприйняття світу. Перечитуючи їх, потрапляєш у своєрідне біополе високої духовності, інтелігентності. I ті мудрі його слова знову глибоко впадають у душу. «Ми - нація Бояна, козака Мамая, Марусі Чурай, ми - нація Соломії Крушельницької, Мишуги, Бориса Гмирі, ми - нація Шевченка, Франка, Лесі Українки, ми - нація Мазепи, Петлюри і Бандери, ми - народ Лисенка, Кошиця та Авдієвського, ми - сама Пісня, Дума, Поезія. I все це при тому, що ми дали супротив всім заборонам, які сипалися на нас, як з рогу достатку...» $(08.08 .2003$ р.) [10, с. 5].

Досліджуючи особистість Анатолія Грицая як композитора, доволі складно відокремити його від бандури. Перебираючи струни бандури, він глибоко вкорінював у своїй душі українську смисложиттєвість. «Бандура - гарячий подих століть, який ми відчуваємо, коли серцем припадаємо до грому віщих струн,» - говорив Анатолій Юхимович [10, с. 5].

Враховуючи недостатню забезпеченість класу бандури педагогічним репертуаром, Анатолій Грицай на високому професійному рівні писав оригінальні композиції та обробки українських народних пісень для голосу в супроводі бандури. Також було написано декілька інструментальних п’єс («Скерцо», «Варіації», обробки ураїнських народних пісень) для учнів музичних шкіл.

Ці твори є досить цінними у художньому плані. Вокальні мініатюри Анатолія Грицая ціла галерея образів, крізь які прозирає духовний образ українства. Добираючи поезію до своїх композицій, Анатолій Юхимович передусім віддавав перевагу тим, які пробуджують правдиві людські почуття - радість і смуток, ніжність і зворушливість, любов до ближнього і відданість суспільним ідеалам. Добрий знавець українських музичних традицій і природи співу, композитор досягнув органічного поєднання словесного та звукового ряду. Розкриваючи зміст вірша, Анатолій Грицай знаходив переконливі у кожному нюансі музичні інтонації, цікаві гармонічні, ритмічні та фактурні рішення.

Анатолій Юхимович не систематизував власні твори. Він часто не зазначав свого авторства в рукописах. Проте вшанування і належна оцінка композиторському спадку А. Грицая, - це, насамперед, виконання його творів, яке давно вже перейшло межі класу бандури в Рівному. Нині твори Анатолія Юхимовича звучать у різних регіонах України та за їі межами.

Пісенна творчість складає основну частину творчого доробку А. Грицая. Він не раз звертався до поезій славнозвісної української поетеси Лесі Українки. Чимало співаків виконували пісні Анатолія Грицая на слова Володимира Сосюри та Дмитра Павличка «Не стелися, тумане» та «Колискова». Привертали увагу композитора і тексти рівненських поетів, зокрема Надії Хільчук та Івана Пащука - «Ой летіли гуси», «Співає Полісся». Особливою популярністю користувалася пісня «Вербиченька», слова і музика Анатолія Грицая. Величезним внеском Анатолія Грицая в розвиток бандурного мистецтва $\epsilon$ написання ним дитячих творів для бандуристів-початківців. Він добре відчував, як заняття музикою зробити цікавими і корисними, тому створював для дітей пісні 3 доступними текстами та зрозумілими музичними образами. На цих мініатюрах виховувалися всі бандуристи Рівненщини, адже майже всі викладачі музичних шкіл області є або його учнями, або учнями його учнів. 
Анатолій Грицай працював над створенням репертуару для дітей з 1931 р. до кінця життя. Створені пісні у процесі роботи Анатолія Грицая із учнями педагогічної практики РМУ, враховуючи музичні здібності і виконавські особливості бандуристів-початківців. Першу збірку творів було видано після смерті автора в 2007 р. - «Бринять душі моєї струни». В яку увійшли авторські твори й обробки українських народних пісень. У цьому ж році було видано «Варіації» на тему української народної пісні «Там, де ятрань круто в'єТься».

3-понад 500 виявлених поезій, залишених Анатолієм Грицаєм, у спадщину нам, більшість, як вже згадувалося, прямо чи побічно описують, прославляють бандуру як персоніфікаційний образ виразника мислення, душі і серця поета. Та чимало поезій іншого спрямування, інших за тематикою, за способами віршування [9, с. 7]. Низка віршів присвячена видатним особам, бандуристам Сергію Баштану, Андрію Бобирю, Михайлу Барану, Людмилі Посікірі, Миколі Чорному, своєму вчителю Володимиру Андрійовичу Кабачку, поету Олексі Ющенку, своїм учням - Галині Топоровській та багатьом іншим. Часто писав Анатолій Юхимович свої присвяти вночі перед приїздом когось із відомих особистостей у Рівне. Багато з тих шедеврів розлетілися в листах по всій Україні і світу. Можливо згодом старанний збирач спадщини Анатолія Юхимовича їх віднайде.

У 2008 р. вийшов збірник його поезій «Бандура - душа моя», що вміщує його найкращі вибрані твори. Збірник містить три розділи - у першому зібрано поезію про бандуру, у другому розділі - сонети та лірика, а третій містить вірші-мініатюри.

Із 2011 р. дитячий обласний конкурс бандуристів носить ім'я А. Ю. Грицая. Він проводиться щороку в Рівненському музичному училищі РДГУ. Його головними організаторами є вихованці А. Грицая - Г. М. Топоровська (голова обласного відділення Національної спілки кобзарів України, викладач-методист Рівненського музичного училища РДГУ, заслужена артистка України) та Н. О. Волощук (заступник голови обласного відділення Національної спілки кобзарів України). Конкурс сприяє виявленню та підтримці талановитих виконавців-бандуристів і популяризації творчості А. Ю. Грицая на Рівненщині.

Отже, творчий доробок А. Грицая мимоволі піднімає культурологічний аспект аналізу. Адже його можна розглядати як зримий свідокі мистецький документ духовного життя українців у період радянської доби. Більшість творів композитором була написана у 1970-1980 pр. Разом із тим твори Анатолія Юхимовича дивовижним чином передають нам атмосферу часу, в якому він працював. Часу, який сам митець сприймав як очікування весни для українства, період пробудження національної свідомості спільноти, історично приреченої на самостійну державу. Його творча діяльність надзвичайно багата та різноманітна і потребує подальшого дослідження.

\section{Jimepamypa:}

1. Баштан С. В. Бандуристе, орле сизий: Віночок спогадів про Володимира Кабачка / С. В. Баштан, Л. Я. Іваненко. - Київ : Муз. Украӥна, 1995. - 134 с. 2. Береза Ю. Просто Анатолій Грицай / Ю. Береза // Рівне плюс. - 1998. - №35. - С.7. 3. Береза Ю. Струни багатої душі / Ю. Береза // Вільне слово. - 1995. - №25. - С.3. 4. Ваврик О. Кобзарські школи в Украйні / Ваврик О. - Тернопіль : Збруч, 2006. - 221с. 5. Гайдамашко А. Бандура- 
доля моя, щзастя моє / Бандура А. // Вісті Рівненщини. - 1992. - №14. - C.4. 6. Гайдамашко А. Творчі ритми Анатолія Грицая / Гайдамашко А. // Народна творчість. - 1997. - №7. С.9. 7. Гайдамашко А. Через ту бандуру... / Гайдамашко А. // Вільне слово. - 1998. -№2. C.5. 8. Гайдамашко А. Творчі ритми Анатолія Грицая / А. Гайдамашко // Народна творчість. - 1997. - №7. - С.6. 9. Грицай А. Бандура - душа моя / А. Грицай. - Рівне, 2008. - C. 99 - 101. 10. Грицай А. Бринять душі моєї струни: Педагогічний репертуар для бандури / Ред. - упор. Т. Ю. Прокопович. - Рівне, 2007. - 80 с. 11. Давидов М. А. Проблеми збереження і розвитку академічного народного інструментального мистеитва України. Київ : НМАУ, 2008. - 404 с. 12. Дачков А. Анатолій Грищай. - Рівне, 2000. - 30 с. 13. Дачков А. Бандура живе скрізь, де живе Украӥнеиь / А. Бандура // Робітнича газета - 1992. - № 22. C.5. 14. Дацков А. Одержимість / А. Дацков // Вісті Рівненщини. - 1997. - №37. - C.5. 15. Дачков А. Фанат? Дивак? Подвижник! / А. Дачков // Сім днів. - 1995. - № 13. - С.8-9. 